\title{
Utilization of the Biorreactor of Imersion by Bubbles at the Micropropagation of Ananas comosus L. Merril
}

\author{
Gessiel Newton Scheidt ${ }^{1}$, Andréa Haruko Arakaki ${ }^{1}$, Jacqueline Sugitani Chimilovski ${ }^{1}$, \\ Augustus Caeser Franke Portella ${ }^{1}$, Michele Rigon Spier ${ }^{1}$, Adenise Lorenci Woiciechowski ${ }^{1}$, \\ Luiz Antonio Biasi ${ }^{2}$ and Carlos Ricardo Soccol ${ }^{* *}$ \\ ${ }^{1}$ Departamento de Bioprocessos e Biotecnologia; Universidade Federal do Paraná; C.P.: 19011; 81531-970; \\ Curitiba - PR - Brasil. ${ }^{2}$ Departamento de Fitotecnia e Fitosanidade; Universidade Federal do Paraná; C.P.:19061; \\ 81531-990; Curitiba - PR - Brasil
}

\begin{abstract}
The research for new techniques of in vitro cultivation is being object of many studies around the world, in order to optimize and decrease production costs of seedlings with agronomical interest. The main goal of this work was to compare different systems of in vitro cultivations using Ananas comosus L. Merril. So, the in vitro growth of the plantlets was promoted in two different bioreactors: Bioreactor of Immersion by Bubbles (B.I.B. ${ }^{\circledR}$ ) and the Reactor of Temporary Immersion (R.I.T.A. ${ }^{\circledR}$ ) with immersion cycle every 2 hours for 15 minutes and the traditional system in flasks with $200 \mathrm{~mL}$. All cultivation systems used the MS liquid nutritive solution, supplemented with BAP $\left(1 \mathrm{mgL} L^{-1}\right)$, ANA $\left(0.25 \mathrm{mgL}^{-1}\right)$, sucrose $\left(30 \mathrm{gL}^{-1}\right)$ and Tween $20^{\circledR}(0.5 \mu \mathrm{L})$. The $\mathrm{pH}$ was adjusted to 5.8 and sterilized at $120^{\circ} \mathrm{C}$ for 15 minutes. The cultures were kept into a growth room during 30 days, with controlled temperature of $25 \pm 2{ }^{\circ} \mathrm{C}$, under white cold light $\left(46.8 \mu \mathrm{mol} . \mathrm{m}^{-2} . \mathrm{s}^{-1}\right)$, with photoperiod of 16 hours. The experimental design used was randomized, with three treatments, three repetitions and ten plants each stage. Among the evaluated systems, the $B I B^{\circledR}$ presented the best results for the tested variables, mainly the total number of shoots, being 2.3 e 3.1 times superior when compared with the system R.I.T.A. ${ }^{\circledR}$ and the traditional consecutively. So the system of immersion by bubbles turns into an effective equipment to produce seedlings of pineapple in large scale.
\end{abstract}

Keywords: Bioreactors, Ananas comosus, micro propagation.

\section{INTRODUCTION}

Originated from the South America, pineapple (Ananas comosus L. Merril) is a monocots plant, herbaceous and perennial from the family Bromeliacea, found distributed between $15^{\circ} \mathrm{N}$ to $30{ }^{\circ} \mathrm{S}$ of latitude and $40{ }^{\circ} \mathrm{L}$ to $60^{\circ} \mathrm{W}$ of longitude, corresponding at South America to the regions southeast and center-west of Brazil, North of Argentina and Paraguay (Collins, 1960).
According to IBGE (2008), the pineapple harvest at Brazil was of 1,810,074 unities all over 82.719 hectares in 2007, and the production estimate in 2,024,541 fruits in 78.706 hectares for 2008, decreasing $4.85 \%$ at the planted area but increasing $11.85 \%$ at the final productivity, turning into the second major world producer. At the national scenario, the state of Para is the main producer (15.525 ha), followed by Paraiba (13.110 ha), Bahia (10.636 ha) and Minas Gerais (10.522

*Author for correspondence: soccol@ufpr.br 
ha), with expressive increase of cultivation, at the south of Pará and Tocantins. As the production increases each year due to the incorporation of new techniques, it provides an important contribution to the population, creating jobs and contributing to keep men at the field.

Aghion and Beauchesne first wrote about pineapple micropropagation in 1960, however, the first report about the use of bioreactor to vegetal propagation was done by Takayama and Misawa (1981), using the propagation of begonia. Immediately, the most important European nurseries producing several millions plants per year, were interested in this technique (Mohan et al., 2005).

Recently Teisson and Alvard (1994) have proposed the plant cultivation in temporary immersion system. The same system is being used at Asia, Europe, South and North America, to propagate plants with agronomical interest, mainly fruits, forestal and ornamental species.

According to Rech Filho (2004) and Silva et al. (2007) the cultivation in bioreactors systems can be divided into continuous and temporary. Teixeira (2002) reports that these equipments use liquid culture medium, they can renovate air during the cultivation and they allow the control of some essential parameters to the growth, such as $\mathrm{pH}$, dissolved oxygen, temperature, ion concentration.

When it is required to increase production to large scale, the bioreactor systems are options to be considered, because they reduce the production costs of seedlings originated from somatic embryo, cells suspensions or whole organs (Silva et al., 2007). Many authors relate the success of cultivation when using bioreactors with species such as banana (Lemos et al., 2001), sugar-cane (Lorenzo et al., 1998), orquidea (Paek et al., 2001) and pineapple (Escalona et al., 1999; Guerra et al., 1999; Feuser et al., 2001; Silva et al., 2007). They report higher multiplication rates when compared with the traditional system. Lemos et al. (2001) describes that the cultivation in bioreactor increases the productivity and accelerates the growth, due to the better area contact of nutrient absorption, since the nutrients can be absorbed by the leaves, stalks and roots.

The Bioreactor of Immersion by Bubbles (B.I.B. ${ }^{\circledR}$ ) developed and patented by Soccol et al. (2008) represents a new alternative for in vitro production of seedlings with economical value, since it is easy to build and to use, consequently it results in low costs. Another advantage is the possibility of use many stages which permits to propagate at the same time different cell strains. In theory, plants can absorb more nutrients in the immersion by bubbles system than in the traditional system, and consequently, increase the final productivity, reducing the cost per unity of plant.

The present work has the main objective to compare the pineapple growth in different in vitro cultivation systems.

\section{MATERIAL AND METHODS}

\section{Explants sources}

Plantlets of pineapple Ananas comosus L. used at the experiments were obtained from the growth in vitro of axillaries buds in MS liquid media (Murashige and Skoog, 1962), supplemented with $1 \mathrm{mgL}^{-1}$ of BAP, $0,25 \mathrm{mgL}^{-1}$ of ANA, $30 \mathrm{gL}^{-1}$ of sucrose, and $\mathrm{pH}$ adjusted to 5,8. The cultivations were done in growth room for 60 days, under photoperiod of 16 hours, temperature of $25 \pm 2^{\circ} \mathrm{C}$ and irradiance of $46.8 \mu \mathrm{mol} . \mathrm{m}^{-2} . \mathrm{s}^{-1}$ furnished by fluorescents lamps "white-cold" type. Thirty days before this experiment, the shoots were separated and transferred individually to the culture medium (MS) with a half of the salts and vitamins concentrations, under the same conditions described. The rooted plants, with more or less 1.0 $\mathrm{cm}$ height, were selected and transferred to the different in vitro cultivations systems.

\section{Experiment}

The experiments were conducted at the Vegetal Biotechnology Laboratory of the Biotechnological Process Pos-Graduation Course, Federal University of Paraná.

Three different cultivations systems were tested: A) Traditional System (control) using $200 \mathrm{~mL}$ flasks of glass; B) Bioreactor with the R.I.T.A. ${ }^{\circledR}$ system; C) Bioreactor with the B.I.B. ${ }^{\circledR}$ system, both with continuous aeration.

In these experiments the culture medium used was MS liquid cultivation medium (Murashige and Skoog, 1962), supplemented with $1.0 \mathrm{mgL}^{-1}$ of BAP, $0.25 \mathrm{mgL}^{-1}$ of ANA, $30 \mathrm{gL}^{-1}$ of sucrose, 1 $\mathrm{mgL}^{-1}$ of thiamine with $0.5 \mu \mathrm{L}$ of $\mathrm{Tween}^{\circledR} 20, \mathrm{pH}$ 
ajusted to 5,8 and sterilized at $120^{\circ} \mathrm{C}$ during twenty minutes. Both bioreactors were fulfilled with $200 \mathrm{~mL}$ of culture medium and the flasks of traditional system (control) with $20 \mathrm{~mL}$. The cultivations were done inside a growth room for 30 days, under photoperiod of 16 hours, temperature of $25 \pm 2^{\circ} \mathrm{C}$ and irradiance of 46.8 $\mu$ mol. $\mathrm{m}^{-2} . \mathrm{s}^{-1}$, furnished by fluorescents lamps kind "white-cold".

The R.I.T.A. ${ }^{\circledR}$ system (Fig. 1 A): "Reactor of Automatized Temporary Immersion", developed by Alvard et al. (1993) is composed by three flasks with two compartments, one superior and one inferior connected by hoses of silicone. According to Malosso (2007) the system is being used by bio factories that obtained success propagating of many species, mainly banana, citrus, coffee, pineapple and sugar-cane by organogenesis or by somatic embryogenesis.
The B.I.B. ${ }^{\circledR}$ system (Fig. 1 B): "Bioreactor of Immersion by Bubbles", developed by Soccol et. al. (2008) is used to produce many trees, ornamental and forestal species. The equipment is made with cylindrical Blindex ${ }^{\circledR}$ glass, with two compartments, divided transversally by a porous plate with 170 a $220 \mu \mathrm{m}$ (porosity 1 ). The inferior part has $3.5 \mathrm{~cm}$ height, with the air entrance. The superior part has $24.5 \mathrm{~cm}$ height and at this compartment are placed the tripods with 2 to $5 \mathrm{~cm}$ height each, angle of $120^{\circ}$ and the sieves (mash 18). All the internal components are made of stainless steel. The bioreactor totalizes $28 \mathrm{~cm}$ height with $90 \mathrm{~mm}$ of diameter, but can be changed according to the needs of the enterprise or institution. The equipment works with an interlinked system with hoses of flexible rubber, through which the vegetal tissues receive air and nutritive solution by bubbling.

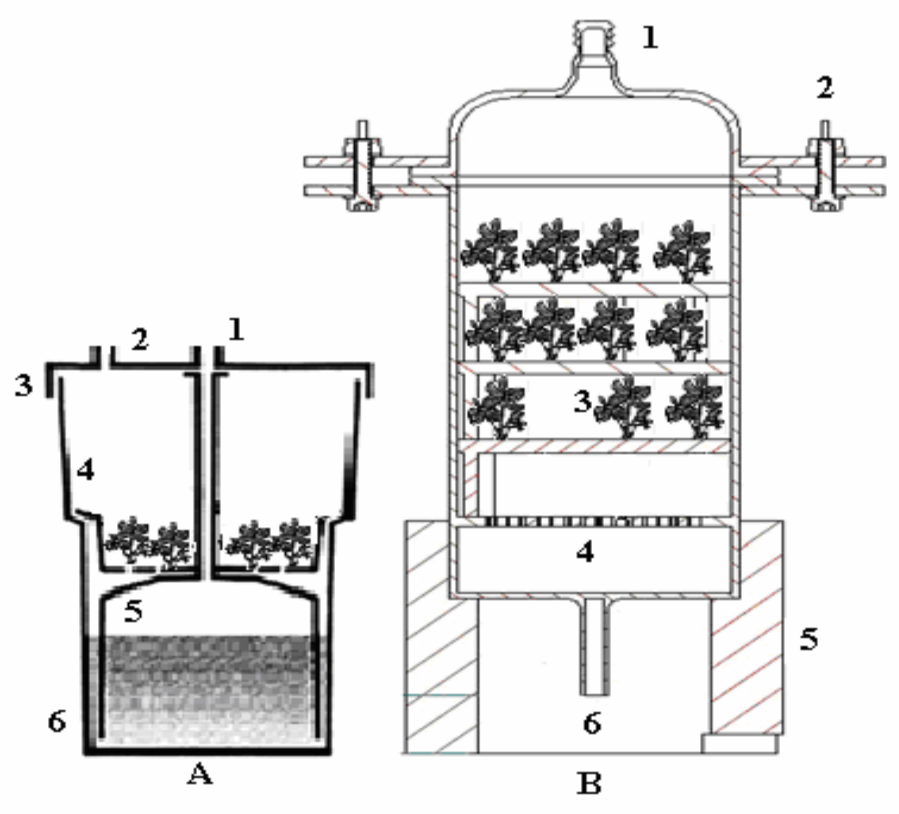

Figure 1 - Schematic design of the bioreactos. Fig. A: (1): Air entrance; (2): Air exit; (3): Fixing cap; (4): Growth chamber; (5): Internal base; (6): Base. Fig. B: (1): Air exit; (2): Fixing device; (3): Growth plates; (4): Porous plate; (5): Base; (6): Air entrance.

\section{Evaluated Variables}

Afer 30 days of cultivation, it was evaluated the following variables:

A) The Total Number of Shoots (TNS); B) Average Number of Leafs Shoots (ANLS); C) Average Number of Roots (ANR): It was estimated using the equipment WINRHYZO $\left.{ }^{\circledR} ; \mathrm{D}\right)$ Average Height of the Plants (AHP); E) Number of Shoots by Plates (NSP); F) Total Fresh Mass (TFM); G) Fresh Mass Increasing (FMI): Obtained by the relationship between the final and the initial fresh mass ; H) Total Dry Mass (TDM).

\section{Experimental Design and Statistical Analysis}

The experimental design was randomized, with three treatments and four repetitions and ten plants 
per experimental unity. All data obtained were submitted to the variance analysis and the averages were compared through the Tukey test at the level of $5 \%$ of error probability. All data were processed using the computational program STATISTICA, according to Ribeiro Júnior (2005).

\section{RESULTS AND DISCUSSION}

From Table 1, it can be seen that the system with immersion by bubbles has stimulated the shoots
2.3 times more when compared to the system of the reactor with temporary immersion and 3.1 times more than the traditional system after 30 days of cultivation. Related to the other variables, the system with immersion by bubbles presented the best performance, mainly related to the average number of roots, 15.52. The average number of leafs shoots did not show significant difference between the two systems of immersion. Silva et al. (2007) reports that the system of immersion is more suitable to the explants growth in liquid cultivation.

Table 1 - Values of the total number of shoots (TNS), number of leaf entries (ANLS), average number of roots (ANR) and average height of plants (AHP) from Ananas comosus L. Merril after 30 days of in vitro culture in different systems.

\begin{tabular}{ccccc}
\hline Treatments & TNS & ANLS & ANR $(\mathbf{c m})$ & AHP $(\mathbf{c m})$ \\
\hline B.I.B. $^{\circledR}$ & $139^{\mathrm{b}}$ & $3.91^{\mathrm{b}}$ & $15.52^{\mathrm{b}}$ & $2.78^{\mathrm{a}}$ \\
R.I.T.A. $^{\circledR}$ & $59^{\mathrm{a}}$ & $3.14^{\mathrm{a}}$ & $11.34^{\mathrm{a}}$ & $2.69^{\mathrm{a}}$ \\
Traditional & $45^{\mathrm{a}}$ & $3.77^{\mathrm{b}}$ & $12.49^{\mathrm{a}}$ & $2.56^{\mathrm{a}}$ \\
\hline
\end{tabular}

Letters with equal treatment in columns do not differ by Tukey test at 5\% level of probability of error.

Other important aspects are the homogenization of the culture medium and the aeration time provided by the bioreactor. According to Etienne and Bertholy (2002) the cultivation system in bioreactors presents the best results to the bud and embryo cultivations compared to the production of seedlings, such as sugar-cane, banana, pineapple, orquideas and other species with agronomical interest.

Other factor that seems to promote the growth of the explants at the bioreactors is the continuous renovation of the air during the period of the medium bubbling (Lemos et al., 2001).

According to the Debergh (1982) the higher contact area of the explants with the medium, the higher is the absorption of the nutritional compounds and consequently, the major growth rate.

According to Corrêa et al. (2009) the induction of somatic embryos can be affected by the composition of culture medium and light conditions.

The highest efficiency of the immersion by bubbles system related to the space used is showed at Figure 2, where the system allowed a higher proliferation of shoots at the first stage, with an average of 57 shoots. The productivity of each stage at the system of immersion by bubbles is similar to the productivity at the whole reactor of temporary immersion.

It can be seen at Table 2 that there is no significant difference between the evaluated variables; however, the system of immersion by bubbles produced the best results: mainly those related to the total fresh mass production $(26.45 \mathrm{~g})$ and the total dry mass $(0.323 \mathrm{~g})$. Silva et al. (2007) noticed that the system of temporary immersion has stimulated a higher quantity of shoots production, as far as a higher biomass volume of pineapple when compared with the traditional system. Escalona et al. (1999) obtained a $20 \%$ production costs reduction, propagating pineapple in bioreactor of immersion. Lorenzo et al. (1998) noticed with the system of temporary immersion, a multiplication rate of 23.9 shoots in 30 days, six times superior to the traditional system for sugar cane. Cervelli and Senaratna (1995) describe that the cells, embryo and vegetal organs propagation using the bioreactors system cultivation increase the productivity and decrease the costs about $24 \%$ to $35 \%$ per produced unity. 


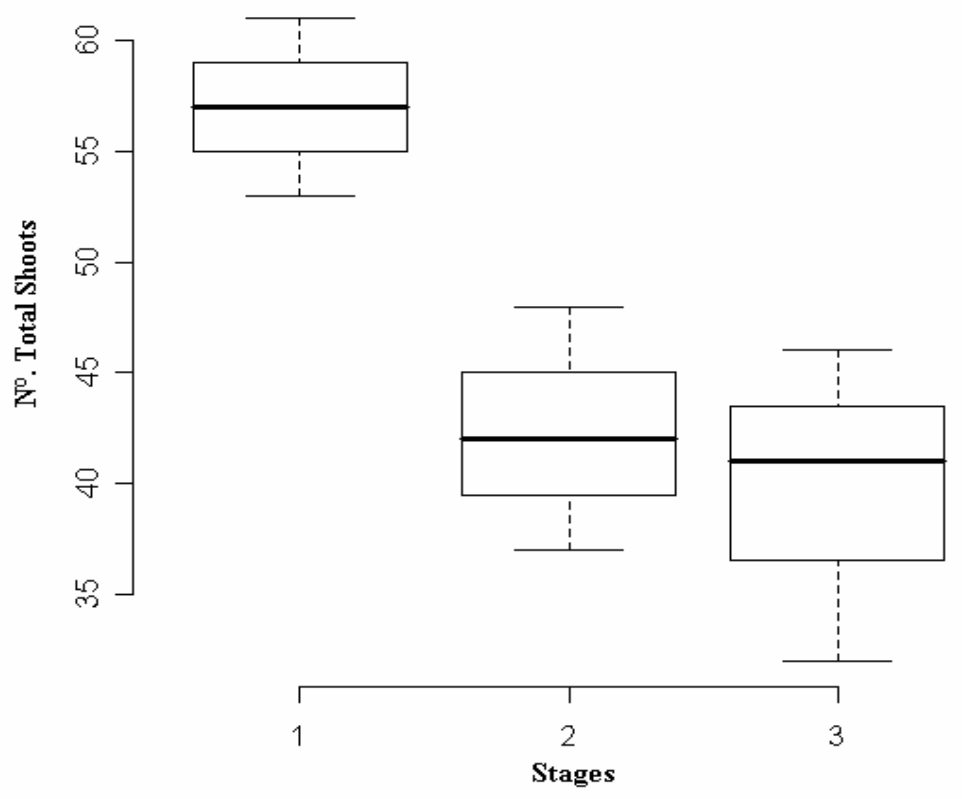

Figure 2 - Average number of shoots with the reactor of immersion by bubbles, in three stages.

Table 2 - Values of Total Fresh Mass (TFM), Total Dry Mass (TDM) and Fresh Mass Increasing (FMI) of Ananas comosus L. Merril after 30 days of cultivation in vitro in different systems.

\begin{tabular}{cccc}
\hline Treatments & TFM $(\mathbf{g})$ & TDM $($ g) & FMI \\
\hline B.I.B. $^{\circledR}$ & $26.45^{\mathrm{a}}$ & $0.323^{\mathrm{b}}$ & $2.80^{\mathrm{b}}$ \\
R.I.T.A. $^{\circledR}$ & $24.36^{\mathrm{a}}$ & $0.243^{\mathrm{a}}$ & $2.72^{\mathrm{b}}$ \\
Traditional $^{2}$ & $23.59^{\mathrm{a}}$ & $0.157^{\mathrm{a}}$ & $1.97^{\mathrm{a}}$ \\
\hline
\end{tabular}

Letters with equal treatment in columns do not differ by Tukey test at 5\% level of probability of error.

It is showed at Figure 3, that the system with immersion by bubbles presents a contact area superior to the other systems evaluated, as far as the stages that increase its propagation capacity. Other advantage is related to the internal space that the system provides, since this equipment has more or less $155.86 \mathrm{~cm}^{3}$ and can be modified in accordance to the enterprise or institution necessities. Other aspect that can be noticed is related to the fact that if to the in vitro cultivated plants is giving the property humidity and light conditions at this phase, they suffer physiologic and morphologic alterations during their development (Mohan et al., 2005; Bandeira et al., 2007). Plants produced at the immersion by bubbles system, under the same conditions of temperature $25 \pm 2^{\circ} \mathrm{C}$ and irradiancy of 46.8 $\mu$ mol. $\mathrm{m}^{-2} . \mathrm{s}^{-1}$, produced bigger shoots multiplication and consequently more vigorous plants. According to Radmann et al. (2001) positive effects were observed at the quality of Gypsophila paniculata $L$. cultivated under photoautotrophic conditions, i.e., under high density of luminous flux, beyond being more vigorous, they are more easily adapted, since they are submitted to minimum alterations at the physic, physiologic and nutritional environment, when they are transferred from the in vitro to the ex vitro conditions.

Therefore, the system of immersion by bubbles represents a new alternative at the ornamental species production scenario, allowing a good nutrition, luminosity and air homogenization, consequently a better productivity. 

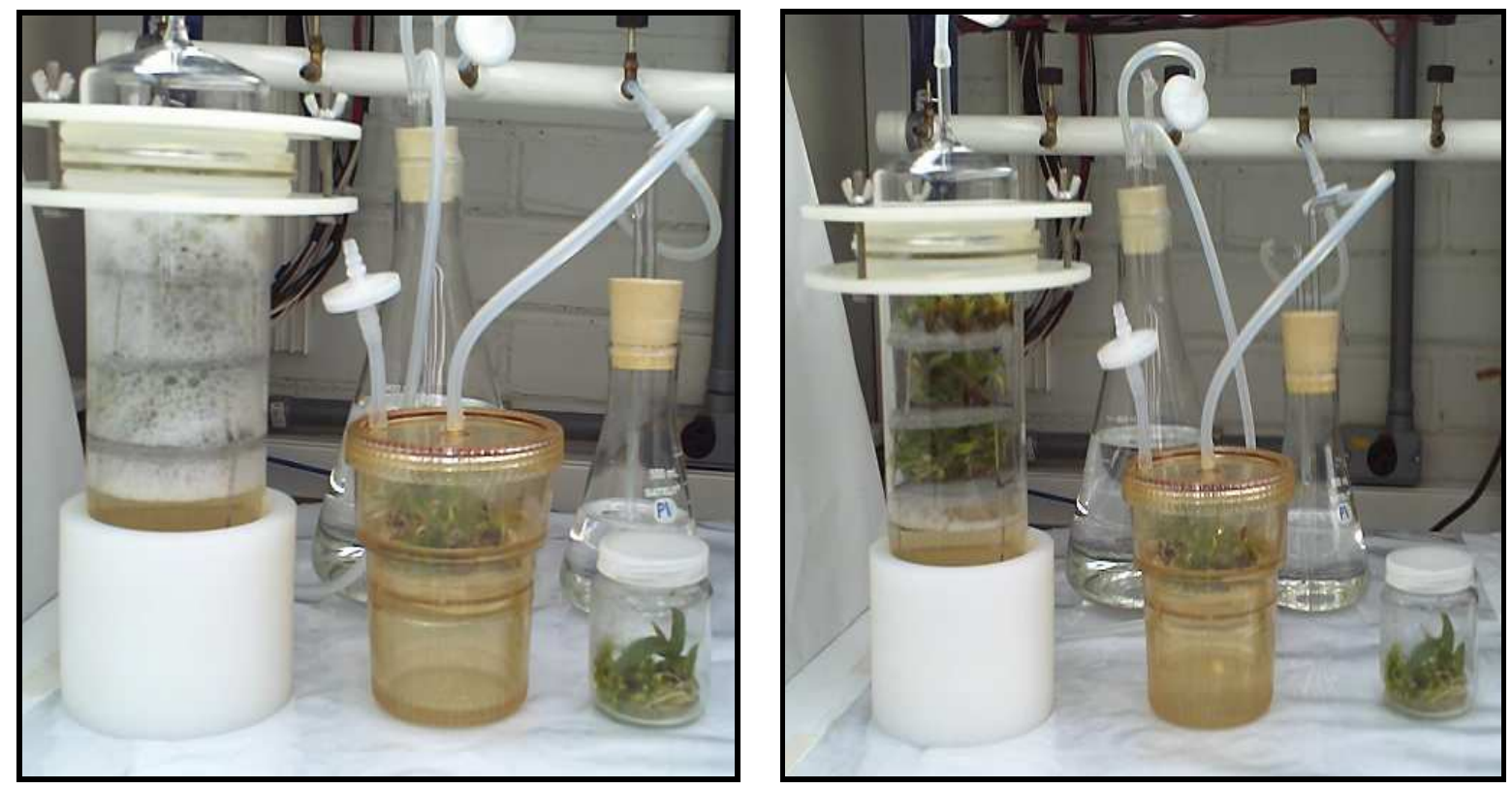

Figure 3 - B.I.B. ${ }^{\circledR}$; R.I.T.A. ${ }^{\circledR}$ bioreactors and traditional system at stage of immersion explants (A) and emersion (B) of Ananas comosus L. after 30 days of culture.

\section{CONCLUSIONS}

The system of immersion by bubbles is the most efficient method to the large scale propagation of pineapple, among the systems tested.

Due to the great adaptability of the equipment to many vegetal species, the system of immersion by bubbles is effective with other species with agronomical value, either in the production of fruits or in the production of forestal species.

\section{RESUMO}

A busca por novas técnicas de cultivo in vitro vem sendo amplamente estudadas, visando otimizar e baixar o custo de produção das mudas que tenham interesse agronômico. O objetivo deste trabalho foi comparar diferentes sistemas de cultivo in vitro de Ananas comosus L. Merril. Para tanto, o crescimento in vitro de plântulas foi promovido em sistemas de biorreatores (B.I.B. ${ }^{\circledR}$ e R.I.T.A. ${ }^{\circledR}$ ) com ciclo de imersão a cada 2 horas por 15 minutos e o sistema tradicional em frascos de 200 $\mathrm{mL}$. Em todos os sistemas de cultivo, foram utilizadas solução nutritiva líquida MS, suplementado com $1 \mathrm{mg} \mathrm{L}^{-1}$ de BAP, $0,25 \mathrm{mg} \mathrm{L}^{-1}$ de ANA, $30 \mathrm{~g} \mathrm{~L}^{-1}$ de sacarose e $0,5 \mu \mathrm{L}$ de Tween $^{\circledR}$
20, pH ajustado para 5,8 e autoclavagem a $120^{\circ} \mathrm{C}$ por 15 minutos. As culturas foram mantidas em sala de crescimento durante 30 dias, temperatura controlada de $25 \pm 2^{\circ} \mathrm{C}$, sob luz branca fria $(46,8$ $\mu$ mol. $\left.\mathrm{m}^{-2} . \mathrm{s}^{-1}\right)$, com 16 horas de fotoperíodo. O delineamento foi inteiramente casualizado, com três tratamentos, três repetições e dez plantas por estágios. Para os sistemas avaliados, o biorreator de imersão por bolhas apresentou os melhores resultados dentre as variáveis analisadas, com destaque ao número total de brotações, sendo 2,3 e 3,1 vezes superiores quando comparado com o sistema R.I.T.A. ${ }^{\circledR}$ e sistema tradicional respectivamente. Portanto, o sistema de imersão por bolhas torna-se um equipamento eficaz na produção de mudas de abacaxizeiro em larga escala.

\section{REFERENCES}

Aghion, D.; Beauchesne, G. (1960), Utilization de la technique de culture sterile d'órganes pour des clones d'Ananas. Fruits, 15, 464-466.

Alvard, D.; Cote, F.; Teisson, C. (1993), Comparison of methods of liquid medium culture for banana micropropagation, Plant Cell, Tissue and Organ Culture, 32, 55-60. 
Bandeira, F. S.; Xavier, A.; Otoni, W. C.; Lani, E. R. G. (2007), Aclimatização ex vitro de plantes propagadas pela enxertia in vitro de clones de Eucalyptus urophylla x E. grandis. Revista Árvore, 31, 773-781.

Cervelli, R. and Senaratna, T. (1995), Economic analysis of automated embryogenesis. p. 29-64. In: J. AITKEN-CHRISTIE, T. KOZAI, and M. A. L. Smith (eds.), Automation and environmental control in plant tissue culture. Kluwer Acad. Publ., Dordrecht, The Netherlands.

Collins, J. L. (1960), The pineapple. Botany, cultivation and utilization. New York, Interscience Publishers. p. 294.

Correa, C. M.; Oliveira, G. N.; Astarita, L. V.; Santarem, E. R. (2009), Plant regeneration through somatic embryogenesis of yacón [smallanthus sonchifolius (poepp. and endl.) H. Robinson]. Brazilian Archives of Biology and Technogy, 52, 549554.

Debergh, P. C. (1982), Physical properties of culture media. In: Plant Tissue Culture. 135-136.

Escalona, M.; Lorenzo, J. C.; Gonzalez, B. L.; Danquita, M.; Gonzales, J. L.; Desjardins, Y.; Borroto, C. G. (1999), Pineapple (Ananas comosus (L.) Merr.) micropropagation in temporary immersion systems. Plant Cell Reports, 18, 743-748.

Etienne, H. and Berthouly, M. (2002), Temporary immersion systems in plant micropropagation. Pant Cell, Tissue and Organ Culture, 69, 215-231.

Feuser, S.; Nodari, R. O.; Guerra, M. P. (2001), Eficiência comparativa dos sistemas de cultura estacionária e imersão temporária para a micropropagação do abacaxizeiro. Revista Brasileira de Fruticultura, 23, 006-010.

Guerra, M. P.; Dalvesco, L. L.; Pescador, R.; Schuelter, A. R.; Nodari, R. O. (1999). Estabelecimento de um protocolo regenerativo para a micropropagação do abacaxizeiro (Ananas comosus (L.) Merr.). Pesquisa Agropecuária Brasileira, 34, 1557-1563.

IBGE. Levantamento Sistemático de Produção Agrícola (LSPA). Rio de Janeiro: IBGE-IBGE Sistema de recuperação automática-SIDRA. Disponível em: (http://www.ibge.gov.br), acesso: 27/09/2008.

Lemos, E. E. P.; Ferreira, M. S.; Alencar, L. M.C.; Oliveira, J. G. L.; Magalhães, V. S. (2001), Micropropagação de clones de banana cv. Terra em biorreator de imersão temporária. Revista Brasileira de Fruticultura, 23, 482-487.

Lorenzo, J. C.; Gonzalez, B. L.; Escalona, M.; Teisson, C.; Espinosa, P.; Borroto, C. (1998), Sugarcane shoot formation in an improved temporary immersion system. Plant Cell, Tissue and Organ Culture, 54, 197-200.
Malosso, M. G. (2007), Micropropagação de Acmella oleracea (L.) R. K. JANSEN e estabelecimento de meio de cultura para a conservação desta espécie em banco de germoplasma in vitro. Tese (Doutorado em Biotecnologia), Universidade Federal do Amazonas, 101.

Mohan, R.; Chui, E. A.; Biasi, L. A.; Soccol, C. R. (2005), Alternative in vitro propagation: use of sugarcane bagasse as a low cost support material during rooting stage of strawberry cv. Dover. Brazilian Archives of Biology and Technogy, 48, 3742.

Murashige, T. and Skoog, F. (1962), A revised medium for rapid growth and bioassays with tobacco tissue culture. Physiologia Plantarum, 15, 473-497.

Paek, K. Y.; Hahan, E. J.; Son, S. H. (2001), Application of bioreactors for large-scale micropropagation systems of plants. In vitro Cellular Developmental Biology Plant, 37, 149-157.

Radmann, E. B.; Braga, E. J. B.; Karan, M. A. L.; Posada, M. A. C.; Peters, J. A. (2001), Influência da densidade de fluxo luminoso na qualidade de plantas micropropagadas de Gypsophila paniculata L. Revista Brasileira de Agrociência, 7, 171-175.

Rech Filho, A. Sistemas de imersão temporária e unidades encapsuláveis como ferramentas para a consolidação de protocolos para a micropropagação de bromélias. Dissertação (Mestrado em Recursos Genéticos Vegetais) - Universidade Federal de Santa Catarina, 2004.

Ribeiro Júnior, J. I. (2004), Análises estatísticas no Excel: Guia Prático. Ed. Visoça, 251.

Silva, A. B.; Pasqual, M.; Teixeira, J. B.; Araújo, A. G. (2007), Métodos de micropropagação de abacaxizeiro. Pesquisa Agropecuária Brasileira, 42, 1257-1260.

Soccol, C. R.; Scheidt, G. N.; Mohan, R. (2008), Biorreator do tipo imersão por bolhas para as técnicas de micropropagação vegetal. Universidade Federal do Paraná. Patente, (DEPR. 01508000078), 3 Março.

Takayama, S. and Misawa, M. (1981), Mass propagation of Begonia hiemalis plantlets by shake culture. Plant and Cell Phisiology, 22, 461-467.

Teisson, C. and Alvard, D. (1994), A new concept of plant in vitro cultivation in liquid medium: temporary immersion. In: VIII INTERNATIONAL CONGRESS OF PLANT TISSUE AND CELL CULTURE, 1994, Florence. Abstract... Florence: ICPTCC, 54.

Teixeira, J. B. (2002), Biorreatores. Revista Ciência e desenvolvimento, 24, 36-41. 


$$
\begin{gathered}
\text { PAGINA } \\
\text { EM } \\
\text { BRANCO }
\end{gathered}
$$

